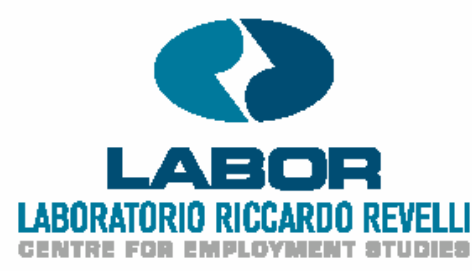

Working Paper no. $\mathbf{5 7}$

The worsening of wage expectations in I taly: a study based on administrative data

\author{
Elena Giarda \\ Prometeia, Bologna \\ Faculty of Statistics, University of Bologna
}

February 2007 


\title{
The worsening of wage expectations in Italy: a study based on administrative data
}

\author{
Elena Giarda ${ }^{1}$ \\ PROMETEIA, Bologna, Italy and \\ Faculty of Statistics, University of Bologna, Bologna, Italy
}

February 2007

Forthcoming in: International Journal of Manpower - Special Issue, 2007

\begin{abstract}
This paper builds on existing studies on the relationship between individual wages, age and experience, and provides new evidence on the determinants of wages in Italy. Using a large panel of individual administrative data, it shows that wage to age profiles for different cohorts of workers are not stable over time: although younger generations of Italian workers are benefiting from higher starting wages than older generations, they face the prospect of lower growth of future earnings. It also confirms the existence of a significant supply effect: the bigger the cohort relative to the active population, the smaller the cohort's gain in terms of wage levels. Finally, it captures the dependence of individual wages on aggregate labour market conditions: individual wages are shown to be negatively related to the rate of unemployment and positively related to the union wage index.
\end{abstract}

JEL classification: J31

1 Address for correspondence: Elena Giarda, PROMETEIA - Associazione per le Previsioni Econometriche, Via G. Marconi 43, 40122 Bologna, Italy. E-mail: elena.giarda@prometeia.it A previous version of the paper entitled "The worsening of wage expectations in the Italian industry sector: a study based on administrative data" was published as PROMETEIA's Working paper No. 0601.

I would like to thank Giovanni Bruno, Claudio Lucifora and Angelina Mazzocchetti for valuable suggestions. The paper also benefited from comments of participants at the XX National Conference of Labour Economics (University of Rome La Sapienza, September 2005) and the IV Brucchi Luchino Workshop (Catholic University of Milan, December 2005). I acknowledge the comments of two anonymous referees which resulted in a major revision of the paper. All remaining errors are my responsibility. 


\section{Introduction and literature review}

The aim of this paper is to test the hypothesis of time-varying wage to age profiles and the dependence of individual wages upon aggregate labour market indicators, for the Italian labour market. The study combines three different aspects of the determinants of individual wages which are usually considered separately: the dependence of individual real wages on age; the impact of supply-side effects; and the relevance of macroeconomic variables such as the unemployment rate and union wages. ${ }^{2}$

The path-breaking studies by Mincer (1958) in the field of human capital stressed how the flow of future individual incomes depends on the education levels and career choices of workers. In these studies, experience (or age, as a proxy for experience) is the driving force of wage formation. This applies both at time of entry to the job market and throughout the workers' professional career, when experience is acquired through learning-by-doing and on-the-job training. Following Mincer's preliminary studies, several authors studied the dynamics of individuals' wages, emphasising the dependence of wages on age. Creedy and Hart (1979) were among the first to extend the analysis of individual wage-age profiles by including a wage-cohort structure. More recently, in a paper on Canadian earnings, Beaudry and Green (2000, p. 919), analysed weekly earnings by means of cohort averages, taken from survey and census data, in thirteen alternate years in the period 1971-1993. They suggest, by extending the analysis to age and cohort interactions, that "recent cohorts ... experience slower wage growth as they age than earlier cohorts did". The notion that wage to age profiles may not be invariant over time is also addressed in studies dealing with the estimation of returns to education. As far back as 1979, Psacharopoulos and Layard argued that the gradient of the wage-age profiles was positively correlated with educational attainment. Brunello and Comi (2000), in a study that utilises individual cross-sectional data from eleven European countries, from the early eighties to the early nineties, show that the slope of the wages to age profiles depends on the investment in education.

An important strand in the literature has investigated the effects of supply factors on individual wages, testing the hypothesis that larger cohorts, resulting from demographic cycles, have a negative effect on wages. Korenman and Neumark (2000) provided some new evidence on this hypothesis, confirming Berger's (1985) results. Using the same data as Welch (1979), but with less restrictive model specifications, Berger concluded that cohort size had the effect of "slowing" earnings growth at the

\footnotetext{
2 'Union wages' are wages determined at national level through collective bargaining.
} 
beginning of a worker's career. Stapleton and Young (1988) found that workers belonging to larger cohorts needed to adjust their educational attainment substantially in order to maximise their lifetime income. Card and Lemieux (2001) explained the wage gap between college and high school in the US, UK and Canada as equating with changes in the relative supply of highly educated workers across age groups. Fertig and Schmidt (2003) show that the evidence related to cohort size effects is weaker for Europe than for the US. Brunello and Lauer (2004) found that the impact of cohort size and educational composition of the labour force on wages is relatively larger in southern than in the northern Europe. Brunello et al. (2000) studied ten European countries and came to the conclusion that institutional factors play an important role in determining the evolution of wage differentials among cohorts. Naticchioni et al. (2006, p. 1) use repeated cross-sections for the years 1993-2004 (Bank of Italy data on Italian wages) and find that "returns to education decline over time almost uniformly across the wage distribution".

A parallel field of research, bridging micro and macroeconomics, has concentrated, in Card's (1995, p. 785) words, on "the examination of the role that local unemployment plays in pay determination". Card was referring to the seminal work of Blanchflower and Oswald (1994), in which the "the wage-curve" is defined as the relationship between individual wages and unemployment. They estimate an elasticity of individual wages to unemployment of -0.10 for the US and many other countries, including Italy. Baltagi and Blien (1998), for example, found an elasticity of -0.07 for Germany, and Bell et al. (2002) estimated a percentage response of wages to changes in unemployment of -0.025 for the UK. Very recently, and using administrative data for Italy, Devicienti et al. (2006) estimated an elasticity of -0.041 for females and of -0.029 for males, for the period 1993-1999. Of course, many scholars have researched this field, and we are not aiming to provide an exhaustive list of examples as estimation of the wage-curve per se is not the main focus of this study.

Lucifora and Origo (1999) stressed the relevance of institutional factors on individual wages. They raise the issue of union versus non-union wages, with respect to wage relativities and wages growth. A similar position is taken in Manacorda (2004), who studies the impact of wage indexation mechanisms (the "scala mobile") on Italian wages in the period 1977-1993. Union wages are to be considered a conditioning factor of the macro-economic environment in which individual wages are determined.

Regarding Italy specifically, Lucifora and Rappelli (1995), Lucifora and Vignocchi (1997), and Brugiavini and Peracchi (2003) use micro-data drawn from the National Institute of Social Security (INPS) administrative archives, to test the hypothesis of wages being dependent on age. In Lucifora and Rappelli's (1995) study, the cohort 
dummies are all shown to be positive and increasing: younger cohorts benefit from higher wages at entry to the labour force than older ones. Better job qualifications, larger sized companies and location in northern regions were also found to generate higher wage levels. Women face lower entry wages than men, though, as Lucifora and Vignocchi (1997) demonstrate, the gap between women's and men's entry wages is progressively decreasing. Brugiavini and Peracchi (2003), in introducing age at degree 3, illustrate that the prospects for earnings growth are less rosy for women. The specification of their model also includes variables such as the imputed years of contribution (estimated on the basis of the Bank of Italy's Survey on households' income and wealth) to account for on-the-job experience gained outside the INPS social security programme. Biagi (2003), based on Beaudry and Green's (2000) methodology, analyses synthetic cohort average wages, through repeated crosssections of survey data. He provides some evidence of a time-varying wage to age structure for male workers and of the evening out of wage to age profiles among more recent generations. The modest statistical significance of the interaction between age and cohort effects prompted us to investigate the issue further.

Varying wage to age profiles are at the basis of our study, which focuses on workers in the Italian industry and service sectors. The paper provides new evidence on the determinants of the dynamics of individual wages exploiting a longitudinal dataset of administrative data on wages for the period 1985-1999. Although it does not propose a novel theoretical approach to individual wage analysis, it demonstrates, building on existing studies, the benefits of a more integrated empirical analysis of individual wages. First, it tests the assumption that the age profiles of individual wages are timedependent: due to a variety of factors - the most prominent perhaps being the progressive slowdown of the Italian economy - younger generations of Italian workers face a lowering of their life-time wage expectations. Second, it investigates the effects of supply factors, such as the changing age structure of the active population, on individual wages. Third, it searches for evidence on the effects of macroeconomic conditions in the labour market by testing the relevance, in the individual wage equation, of variables such as unemployment rate and real union wages index.

The work is organised as follows. Sections 2 provides a description of the dataset used in the analysis. Section 3 presents ordinary least squares (OLS) and random effects estimations of the cohort model, which includes changing-over-time wage to age profiles. In addition to the usual control variables, the model specification includes number of years of social security contributions as a proxy for on-the-job experience. Section 4 extends the analysis by testing the effects of cohort size (as an indicator of supply-side effects), and of aggregate labour market variables (regional unemployment 
rates and union wage index). Section 5 concludes with a summary of the main findings.

\section{The data}

The dataset used in this paper is the WHIP ${ }^{3}$ (Work Histories Italian Panel), a database built out of INPS administrative archives, which contains the work histories of a sample of workers from 1985 to 1999. The paper concentrates on industry and service sector workers, aged 18-60, and born between 1925 and 1981. The number of individuals in this extracted sample is 99,825 ( $84.7 \%$ of the original dataset), among which 38,714 are females (38.8\% of the total) and 61,111 are males $(61.2 \%$ of the total). Table 1 presents the cohort composition. For those individuals with more than one employment spell within the same year, the total yearly wage is computed by adding together all intra-year wages. ${ }^{4}$ As far as individual characteristics (work area, sector, qualifications, etc.) are concerned, those that prevailed for the longest in any intra-year spell were applied.

Take in TABLE 1, TABLE 2, TABLE 3, TABLE 4 and TABLE 5

Mean annual nominal and real wages for full-time workers in the sample (Table 2) show high variability, with growth rates of around $2 \%$ in real terms at the end of the eighties and negative growth rates in the second half of the nineties. Females' average weekly real wages for the entire 15-year period are consistently lower than males' (Table 3). The average wage by age class from 1985 to 1999 remains relatively stable over time for young workers, but shows significant increases for older workers (Table 3). Weekly real wages in the industry sector are an average $3.6 \%$ higher than in the service sector, with a percentage difference between the two sectors of as much as $17.5 \%$ for white collar workers (Table 4 ). Earnings in northern Italy are higher than in the rest of the country, by as much as 90 euros per week, corresponding to a difference of $33.7 \%$ compared to the Isles. Also workers employed in larger companies

3 WHIP, Work Histories Italian Panel, is built and distributed by Laboratorio R. Revelli - Centre for Employment Studies, Moncalieri - Italy, http://www.laboratoriorevelli.it/whip. The section of WHIP used in the paper is a linked employer-employee database, that combines information on private sector employees with information on the companies that employ them. WHIP is based on a systematic random sampling of approximately 1 in every 180 individuals of the INPS individual files (the sampling is based on dates of birth). The original sample contains 117,785 individuals (41,347 females and 76,438 males, with a percentage composition of 35 and $65 \%$ respectively) working in all branches of the private sector, for a total of 937,152 observations over the period 1985-1999. The fact that individuals who are shown as having had more than one employment spell in the same year, reflects that they took up new employment within that year or that they had two part-time jobs; or perhaps is due to the precision and speed at which INPS registers job movers in its archives.

4 Wages are net of social security contributions payable by the employer, but gross of income tax and social security contributions payable by the employee. 
benefit from higher real wages (Table 5). The average real wage ${ }^{5}$ for full-time workers in the sample increases over time in line with the same pattern for the National Accounts (NA) average wage (Figure 1 ).

\section{Take in FIGURE 1}

Before turning to the analysis, we need to point to some limitations of our dataset. For example, it provides no information on education level, and does not follow private employees enrolled in other social security schemes. It does not provide information on reasons why workers leave the archive: this can be due to periods of unemployment, mobility towards and from self-employment and public employment, or retirement. As a result, there may be some problems of attrition, as discussed by Cappellari (2000). However, controlling for the related sample selection bias, via the Heckman (1979) procedure, would be problematic because of the limited information available within WHIP. Following Cappelllari's judgment that "the use of a dataset with an unbalanced design partially mitigates the problem" (p. 667), the decision was taken to ignore this problem. Annual wages are also characterised by a top-coding at 60,000 euro, but no specific treatment is given to this problem of censoring because the censored observations account for less than 0.6 percent of the sample size.

\section{The cohort structure of wage to age profiles}

The analysis of the determinants of individual wages is based on panel data and includes cohort variables to capture generational differences in wages. The present paper starts by considering the cohort effects as treated in models such as Lucifora and Rappelli (1995) and Lucifora and Vignocchi (1997).

It then takes into account suggestions presented in Beaudry and Green (2000) for Canada, and Biagi (2003) for Italy, on the interaction between age and cohort effects, to analyse the determinants of individual wages in the industry and service sectors in Italy. Their model specification includes an interaction variable defined as the product of age and cohort. Our analysis improves on these studies in several aspects. It applies to both male and female workers. It uses a large sample of individual longitudinal administrative data, rather than cohort average values of real wages, taken from cross-sectional survey data. It covers a period of fifteen consecutive years from 1985 to 1999 , instead of seven waves of cross-sections on alternate years from 1984 to 1995 (Biagi, 2003), or thirteen in the period 1971 to 1993 (Beaudry and Green, 2000). In terms of model specification, the interaction between age and cohorts is defined on

\footnotetext{
5 As a deflator of nominal wages we used the earnings conversion coefficients provided by INPS and utilised to compute social security benefits ("Coefficiente di rivalutazione quota $A$ ").
} 
an individual basis, rather than on cohort averages. The use of individual data allows us to account for individual control variables, such as geographical area, job qualifications, sector of employment, firm size and part-time work. Furthermore, it allows us to test the interaction of the age-cohort structure with the propositions derived from the wage-curve literature, and the effects of union wages on individual earnings.

The hypothesis to be tested in this section is that wage to age profiles - affected by the sluggish growth of the Italian economy and by the slowdown in average wage growth rates - may present a slope of decreasing value for younger generations of workers. This section first presents (sub-section 3.1) estimates of a base cohort model, and then proposes and tests (sub-section 3.2) a specification of the changing wage-age structure over time.

\subsection{The base model}

Traditional econometric models of individual wages express the level of individual wages over time as a non-linear (most frequently, quadratic) function of age, and a linear function of control variables such as gender, sector, job location and job qualifications. They also take account of education levels. Given that the WHIP dataset does not include information on education, our model specification includes the variable 'number of years of social security contributions'. With some approximation, this variable can be seen as a proxy for on-the-job training and work experience.

Individual wages equations estimated on panel data show the relevance of cohort effects. Cohort dummy variables provide estimates of how and by how much the entry wage varies as it moves along the different cohorts of workers.

Taking account of all these variables, the base cohort model can be shown as:

$$
\begin{aligned}
\ln w_{i t}= & \alpha_{0}+\alpha_{1} \text { age }_{i t}+\alpha_{2} \text { age }_{i t}^{2}+\sum_{j=2}^{9} \beta_{j} \text { dco }_{j}+\delta_{0} \text { lcontr }_{i}+ \\
& +\delta_{1} \text { ptime }_{i}+\delta_{2} \text { sect }_{i}+\delta_{3} \text { size }_{i}+\delta_{4} \text { area }_{i}+\delta_{5} \text { qual }_{i t}+\varepsilon_{i t}
\end{aligned}
$$

where $i$ indexes the individual and $t$ the time. Wages, age and qualifications ${ }^{6}$ are individual time-varying variables and are denoted by it. The equation is estimated separately for men and women.

The log of real weekly wages ${ }^{7}$ is thus a function of:

- a second-degree age polynomial;

\footnotetext{
Qualifications are considered time-dependent as career progression can be automatic, regardless of the worker's ability.

7 The choice of weekly wages is justified by the risk of an under-reporting bias for daily wages.
} 
- cohort dummies $\left(d c O_{j}\right)$, where cohorts refer to workers born in the same five or ten year periods. Older and younger individuals are classified in ten year cohorts, from 1925 to 1935 and from 1971 to 1981 respectively. All other cohorts cover periods of five years (for a percentage composition of the sample by the nine cohorts, see Table 1);

- a set of control variables ${ }^{8}$ : indicating whether the worker is a part-timer (ptime), the sector of employment (sect), the company size (size), the geographical location of the job (area), and the job qualifications ${ }^{9}$ (qual);

- the log for the total years of social security contributions ${ }^{10}$ paid to the INPS during the 15-year period under analysis (Icontr).

In estimating the model the reference individual is assumed to be a full-time whitecollar worker belonging to cohort 1, working in a company of size 20-199 employees, in northern Italy and in the industry sector. The constant term in the regression is thus the value that defines the base wage of this representative worker, and the coefficients associated with cohort dummies measure the effect on wages linked to the different times of entry into the labour force.

The OLS robust estimates ${ }^{11}$ of the model for males (Table 6) show satisfactory goodness of fit statistics with the R-squared of 0.462 in line with the values obtained in similar analyses. However, for women the R-squared is only 0.267 . The estimated coefficients confirm most of our a-priori expectations: ${ }^{12}$ wages are higher in the north, in bigger companies, for better qualifications, and in the industry sector (the dummy associated with services is significant and negative). The number of years of social security contributions has a positive sign in the equation, indicating higher wages for those workers with more on-the-job experience. In line with the existing literature, cohort coefficients are higher for younger workers. ${ }^{13}$ Figure 2 depicts the estimated wage-age profiles for men (which are similar for women): each cohort has a different

8 Variable sect distinguishes between the industry and the service sectors; variable size distinguishes among companies with up to 19 employees, 19-200 employees, and more than 200 employees; variable area captures regional effects (North, Centre, and South \& Isles); variable qual distinguishes among qualifications: apprentices, blue collar workers, white collar workers and managers.

9 The category "white collar" also includes senior officers ("quadri" in Italian), which in the dataset are identifiable only from 1997.

10 Years of contribution refers to the period of enrolment with the INPS only; the dataset does not provide information on how long or whether an employee was a member of another social security scheme.

11 Estimates are obtained using the Huber-White estimator (Huber, 1967; White, 1980).

12 The only exception being the part-time dummy, which has a positive sign in the women's equation, where we would expect a negative contribution. In the men's equation it has a negative sign, although it is not statistically significant.

13 A Wald test on the pair-wise equality of cohort coefficients was performed for both equations. All pairs of adjacent coefficients were significantly different from zero: for women the F-statistic was 150.7 $(p$-value $=0.000)$, for men it was $156.9(p$-value $=0.000)$. 
intercept derived from the sum of the common constant term and the specific cohort coefficient. This defines the entry wage for each cohort.

Take in TABLE 6 and FIGURE 2

\subsection{The model with a time-varying wage to age structure}

The first three terms in equation (1) define a concave wage to age profile that shifts along the different cohorts with a concavity that is assumed to be invariant over the different cohorts. A stable wage to age profile gradient over time somewhat contradicts the widespread opinion (or prejudice), that the wage growth prospects of today's young workers are bleaker than their parents'. The reduction in the growth rate of the Italian economy since the mid 1980s has been accompanied by a decline in the share of wages in national income, and by a slow-down in average wage dynamics. Between 1985 and 1999, both the industry and service national average (NA) wage and the sample average wage show a declining rate of growth. In the first part of the sample, from 1985 to 1991 , the annual average growth of real wages was around $1.8 \%$; in the second part it became negative, about $-0.1 \%$.

These trends prompt questions about the reality of the assumption of stable wage to age profiles that is implicit in the specification of equation (1) with its constant values for coefficients $\alpha_{1}$ and $\alpha_{2}$. An alternative assumption is that younger cohorts of wage earners still enjoy higher real wages than older generations (in line with the predictions of the traditional model), but may face less optimistic prospects of income growth. In such a situation, where the careers of new entrants in the labour market develop at slower annual growth rates than in the past, the assumption of an over-time invariant gradient of the wage to age relation should be rejected.

To test this alternative hypothesis, the wage to age relation described by the first terms in equation (1) is modified to generate the possibility of a different gradient for each cohort (Beaudry and Green, 2000; Biagi, 2003). This is done by introducing a set of variables into the model, defined as "multiplicative age-cohort dummies", obtained from the product of age by each cohort dummy. The expectation is that multiplicative dummies will generate flatter gradients for the wage to age relation, with the passage of time (from older to younger cohorts).

In the revised specification of the model, the log of individual weekly real earnings is thus regressed on the second-degree age polynomial and the already defined set of control variables, with the addition of the set of multiplicative age-cohort dummies. The new model is: 


$$
\begin{aligned}
\ln w_{i t}= & \alpha_{0}+\alpha_{1} \text { age }_{i t}+\alpha_{2} \text { age }_{i t}^{2}+\sum_{j=2}^{9} \beta_{j} d c o_{j}+\sum_{j=2}^{9} \gamma_{j} \text { agedco }_{j t}+\delta_{0} \text { lcontr }_{i}+ \\
& +\delta_{1} \text { ptime }_{i}+\delta_{2} \text { sect }_{i}+\delta_{3} \text { size }_{i}+\delta_{4} \text { area }_{i}+\delta_{5} \text { qual }_{i t}+\varepsilon_{i t}
\end{aligned}
$$

where the variables agedco $_{j t}=d c o_{j} * a g e_{i t}$ are the multiplicative age-cohort dummies. Taken together, the cohort dummies and the multiplicative age-cohort dummies provide measures of both the "additive" cohort effect and the different response of wages to age among the different cohorts, as can be seen more clearly in this respecification of equation (2):

$$
\ln w_{i t}=\sum_{j=2}^{9}\left(\alpha_{0}+\beta_{j} d c o_{j}\right)+\sum_{j=2}^{9}\left(\alpha_{1}+\gamma_{j} d c o_{j}\right) a g e_{i t}+\alpha_{2} \operatorname{age}_{i t}^{2}+e t c .
$$

where the gradient of the wage to age relation is given, for each cohort $j$, by $\alpha_{1}+\gamma_{j}+2 \alpha_{2}$ age. The new hypothesis requires a smaller value of the parameter $\gamma_{j}$ for individuals of the same age belonging to younger cohorts.

Table 7 reports the OLS robust estimates by sex for the parameters of the new wage profiles in equation (2). As in the base model, goodness of fit is satisfactory for men, with an R-squared of 0.463 , but less so for women, with an R-squared of 0.267 . The signs of the control variables are consistent with expectations. ${ }^{14}$

Take in TABLE 7

The pattern of the coefficients associated with cohort dummies shows a regular increase for both male and female workers, confirming the traditional finding that younger cohorts receive higher entry wages. As for the multiplicative dummies, the results of the separate equations for males and females illustrate that their coefficients are all negative (except agedco2, which is non-significant) and progressively increasing in absolute value, as we move from older to younger generations, with the gradient between wage and age becoming flatter for younger cohorts. Both additive and multiplicative cohort coefficients are pair-wise statistically different from zero. ${ }^{15}$ The new wage to age profiles depicted in Figure 3, clearly show that the slopes of each segment become progressively more gradual as we move from older to younger generations, for instance from cohort 6 (older workers born between 1956 and 1960) to cohort 9 (younger workers born between 1971 and 1981).

14 Again, with the exception of the control variable part-time, which is positive for both sexes and nonsignificant for men.

15 A Wald test of the pair-wise equality of multiplicative cohort coefficients was performed on both the women's and men's equations. All pairs of adjacent coefficients were significantly different from zero: for women the F-statistic was 46.3 ( $p$-value=0.000), for men it was 61.9 ( $p$-value=0.000). For additive cohort dummies the F-tests were $60.9(p$-value $=0.000)$ and $77.3(p$-value $=0.000)$ respectively. 
The cohort structure of the model is confirmed by the estimation of a random effects model (which takes account of unobserved individual heterogeneity), as demonstrated by the results in Table 8 . Coefficients of additive cohorts increase from older to younger generations, and those of multiplicative cohorts decrease accordingly. Number of years of social security contributions has a positive impact on earnings levels for both women and men, and area and qualifications dummies are in line with our expectations. ${ }^{16}$ Finally, the estimated individual specific standard deviation is 0.287 for women and 0.211 for men, and the idiosyncratic standard deviation is 0.327 and 0.307 for women and men respectively.

\section{Individual wages and aggregate labour market indicators}

This section provides some evidence on the relevance of aggregate labour market conditions on the dynamics of individual wages. The model described in Section 3.2 is extended to test the effects on individual wages of changes in the age structure of the active population, and the effects of unemployment rate and union wages. The purpose of this section is thus to test the robustness of the wage to age profiles through more detailed model specifications. The aim is not to provide a full-fledged integration of the microanalysis of wage determination with labour market conditions; it is rather to suggest the usefulness of such integrations and possible further development of individual wages analysis.

Age structure of the active population. In the model described in equation (2) none of the explanatory variables is related to labour market conditions. Individual wages and cohort effects are assumed to be independent of changes in the age structure of the population. In light of the changes that have occurred over the last thirty years in the age structure of the active population in Italy, this assumption is not appropriate. Significant studies on the topic, such as those by Welch (1979) and Berger (1985), suggest that supply-side effects are measurable by the relative size of the population by age groups (cohort size). A larger active population in a given age class relative to the total active population, may generate a downward pressure on the wages of workers in that class. In other words, when the size of a cohort increases, it may have a depressive effect on the wages of individuals in that cohort; when it decreases, it may have an expansionary effect on wages.

The yearly cohort size, separately computed for men and women, is given by:

16 Again, the sign of the control variable part-time is an exception. 


$$
C S_{k t}=\ln \left(\frac{\frac{1}{9} N_{(k-2) t}+\frac{2}{9} N_{(k-1) t}+\frac{3}{9} N_{k t}+\frac{2}{9} N_{(k+1) t}+\frac{1}{9} N_{(k+2) t}}{N_{(18-60) t}}\right) \begin{gathered}
k=18, \ldots, 60 \\
t=1985, \ldots, 1999
\end{gathered}
$$

where the numerator is the moving average of individuals in adjacent age groups (with annual age classes indexed by $k$ ) and the denominator is the total population aged 1860. The trend in average size of age cohorts from 1985 to 1999 (Figure 4) shows the progressive ageing of the male Italian labour force and the changing structure of the active population. The pattern is similar for women.

Macroeconomic factors. Studies on the determinants of individual wages, such as Lucifora and Rappelli (1995), and Lucifora and Vignocchi (1997), suggest taking account of temporal effects by means of time dummies. The rationale for year dummies in the individual wage model is that they would remove the mis-specification resulting from lack of consideration of the effects of macroeconomic development on the short-term dynamics of individual wages. However, time dummies, age and cohorts taken together generate over-identified non estimable models. Could this be dealt with, any system of time dummies would not anyway provide a direct identification of the macroeconomic events that affect the behaviour of individual wages. The economic explanation of what has happened is left to the researcher's interpretation of the cyclical history of the economy. Macroeconomic events affect the dynamics of individual wages and thus the model specification has to be controlled "for common across-cohorts business-cycle fluctuations" (Biagi, 2003, p. 8). The problem associated with contemporaneously identifying age, cohort and year effects has been brought to the attention of researchers by Heckman and Robb (1985). As suggested by Burbidge et al. (1997, p. 8) "one way to resolve the problem is to model the effect of one or more of the independent influences (cohort, year or age) as functions of other variables rather than simply including them as fixed effects or trends". This suggests the inclusion of macro variables in the estimating equations, such as unemployment rate and union wages.

Unemployment rate. Over the 15-year history of individual wages examined in the paper, the unemployment rate has shown marked cyclical behaviour, with wide regional differences (Figure 5). It is not unreasonable to assume that the worsening of the overall condition of the labour market might have affected individual wages and the wage to age relation. Blanchflower and Oswald (1994; 1995; 2005), in estimating the wage curves for a variety of countries, including Italy, found a consistent negative relationship between individual wages and regional unemployment rates. In applied macroeconomics studies wage dynamics and unemployment are obviously 
interdependent. The risk of simultaneous equation bias in individual wage equations has been questioned. Blanchflower and Oswald (1995, p. 158) argue that "attractive though such thinking is theoretically, little support for it can be found empirically". The reason being that instrumental variable techniques have not been shown to significantly modify the value of estimated wage to unemployment elasticities. In their words: "Unemployment apparently has the characteristics of a predetermined variable" (Blanchflower and Oswald, 1995, p. 158). To be consistent with the literature and avoid introducing collinearity, we utilise regional unemployment rates ${ }^{17}$ in our model, which includes age and cohort dummies among the regressors.

Union wages. Individual wages are affected by changes in union wages that occur as a result of the quasi-automatic adjustments to inflation and of periodic national level wage negotiations. Such effects can be thought of as almost independent of individual behaviour and apply to all workers. The union wage level is determined by bargaining at national level and is independent of the age structure of the work force. Furthermore, it is closely linked - with lags of varying lengths - to inflation. A positive correlation $(r=+0.38)$ exists between the sample average wage and the union wages index.

The real union wage index (Figure 1) increases up to 1992 due to the prevailing indexation of wages to inflation, which created a mechanism for real wage resistance in case of monetary shocks and changes in indirect taxation (Fabiani et al., 1998). It falls in the period 1993 to 1996 as an effect of the 1993 labour cost agreement, and starts to move upwards again in subsequent years. Overall, it shows fluctuations around a stable mean and, therefore, our expectation is that it is more likely to interfere with the constant term of equation (2) than with the cohort dummies.

\subsection{Estimation}

On the basis of the arguments developed so far, the model is revised to include labour market conditions. The new specification thus adds cohort size, regional unemployment rates and real union wages to the explanatory variables in equation (2):

$$
\begin{aligned}
\ln w_{i t}= & \alpha_{0}+\alpha_{1} \text { age }_{i t}+\alpha_{2} \text { age }_{i t}^{2}+\sum_{j=2}^{9} \beta_{j} \text { dco }_{j}+\sum_{j=2}^{9} \gamma_{j} \text { agedco }_{j t}+\delta_{0} \text { lcontr }_{i}+ \\
& +\delta_{1} \text { ptime }_{i}+\delta_{2} \text { sect }_{i}+\delta_{3} \text { size }_{i}+\delta_{4} \text { area }_{i}+\delta_{5} \text { qual }_{i t}+ \\
& +\vartheta_{1} C S_{i t}+\vartheta_{2} \ln \text { unemp }_{t}+\ln \text { wcontr }_{t}+\varepsilon_{i t}
\end{aligned}
$$

17 The disaggregation of the unemployment rate is at the macro-regional level: North, Centre, and South of Italy. Consistent series of national and regional unemployment rates over the period 1985-1999 were provided by ISTAT (Gatto et al., 2001). 
where the variables in the first two lines of the equation are those defined in Section 3, $C S_{\text {it }}$ is cohort size as defined in equation (3), In unemp $p_{\mathrm{t}}$ is the log of unemployment rates for Italian macro regions and In wcont $_{\mathrm{t}}$ is the log of the real union wage index.

The model is estimated separately for the two sexes using OLS and taking account of the different levels of aggregation of the dependent variable (individual wages) and the newly introduced annual macro variables, to correct for heteroskedasticity and avoid a standard errors bias $^{18}$ (as addressed by Moulton, 1986). Table 9 presents the estimated coefficients of the model.

\section{Take in TABLE 9}

The estimates of additive and multiplicative cohort dummies are statistically significant (with the exception of cohorts 2 and 3 for women). As with the model in equation (2), additive dummies increase from older to younger generations; multiplicative dummies are negative and progressively increasing in absolute value. This confirms the robustness of the changing-over-time cohort structure of individual wages. ${ }^{19}$

The coefficients associated with cohort size are always statistically significant and, as expected, with a negative sign. The associated elasticities are around -0.16 for both females and males.

The elasticity coefficients of the union wage index are 0.93 and 0.72 , for women and men respectively, and are statistically different from zero. The quasi-unitary elasticity of individual to union wages has the effect of keeping the constant term of the equation close to zero and making it statistically non-significant. The high constant term (which has no clear economic meaning), which characterises the simpler models presented in this and some of the studies discussed in Section 1, is now substituted by a significant relation for a macroeconomic variable relevant to the labour market. ${ }^{20}$

The unemployment rate is not statistically significant in the female equation or the two older cohorts in either their additive or multiplicative forms. For men, the estimated elasticity coefficient of regional unemployment rate is significant and equal to -0.053 . This figure is between the values for the UK estimated by Card (1995) and Bell et al. (2002), of -0.082 and -0.025 respectively. It is also well below Blanchflower and

18 Estimates were obtained using the Huber-White (Huber, 1967; White, 1980) estimator of variance as implemented by Rogers (1993).

19 The parameters of the cohort structure estimated in equations (2) and (4) compare favourably with the estimates provided in Biagi (2003), where a large number of the estimated cohort coefficients was not statistically significant, possibly as a consequence of the small number of degrees of freedom. In fact, by using average wages by cohort, the number of observations is necessarily very small.

20 Estimation of model (4) by OLS and random effects, with the inclusion of only cohort size and union wages (among the macro variables), produced satisfactory results for both sexes in terms of the cohort structure, with only cohorts 2 and 3 not statistically significant in the female equation. Individual to union wages elasticity is 1.00 and 0.92 for females and males respectively. As expected the constant term of both equations is not significant. 
Oswald's (1995; 2005) result for the US and other countries including Italy, of -0.10 . It should be noted that our model includes the union wage index, which might interact with the unemployment rate.

To be consistent with previous empirical work on wage-curves, we estimated a model that includes only cohort size and unemployment, as follows:

$$
\begin{aligned}
\ln w_{i t}= & \alpha_{0}+\alpha_{1} \text { age }_{i t}+\alpha_{2} \text { age }_{i t}^{2}+\sum_{j=2}^{9} \beta_{j} \text { dco }_{j}+\sum_{j=2}^{9} \gamma_{j} \text { agedco }_{j t}+\delta_{0} \text { lcontr }_{i}+ \\
& +\delta_{1} \text { ptime }_{i}+\delta_{2} \text { sect }_{i}+\delta_{3} \text { size }_{i}+\delta_{4} \text { area }_{i}+\delta_{5} \text { qual }_{i t}+ \\
& +\vartheta_{1} \text { CS }_{i t}+\vartheta_{2} \ln \text { unemp }_{t}+\varepsilon_{i t}
\end{aligned}
$$

In this case, the estimated elasticity coefficients of regional unemployment rates for men and women are -0.072 and -0.046 respectively (Table 10), and are statistically significant. The estimated value from the male equation compares well with Blanchflower and Oswald's (1995; 2005) and Card's (1995) estimates referred to above. The elasticity estimated in the female equation is rather low, but is comparable with Bell et al.'s (2002) estimate of -0.025 for the UK. For Italy, Devicienti et al. (2006), using the WHIP dataset, estimated an elasticity of -0.041 for females and -0.029 for males for the period 1993-1999.

\section{Take in TABLE 10}

Equations (4) and (5) were estimated with a random effects specification, and to account for the different levels of aggregation among the variables ${ }^{21}$ (Moulton, 1986). Estimates (Table 11) for the male equation of model (4) generally confirm the previous results, but with a slight deterioration in the decreasing pattern of the multiplicativecohort coefficients for the two younger cohorts ( 8 and 9) and loss of significance of the two area dummies. In the female specification, the results show an improvement, with the unemployment elasticity coefficient statistically significant and elasticity estimated at -0.038 . The elasticities between union and individual wages are confirmed (Table 11): 0.88 for women and 0.70 for men. The estimation of equation (5) produces unemployment rate elasticities (Table 12 ) that compare with those estimated via OLS: -0.063 for women and -0.096 for men.

Take in TABLE 11 and TABLE 12

The estimations of equations (4) and (5) thus confirm the robustness of the cohort structure discussed in the previous section.

In both the male and female equations, the wage to age profiles of individual wages remain substantially the same as estimated in equation (2) and depicted in Figure 3,

21 See footnote 18 . 
with the cohort and multiplicative dummies having the correct sign and dimension. Thus, the profile estimates, inclusive of the change over time in wage to age gradients, are robust to the introduction of aggregate labour market indicators.

\section{Summary and conclusions}

This paper builds on the results of existing studies on the individual wage to age relation. It confirms that the younger generations of workers in the Italian labour market have higher entry wages and that they can expect increasing earnings in the future. However, it shows that wage-age profiles cannot be considered invariant over time, and are characterised by progressively smaller gradients as one moves from older to younger generations. As a consequence, the expectations for younger generations of workers are of flattening wage-age profiles: higher entry wages are compensated for by reduced expectations of future earnings growth. These results hold in a variety of model specifications, including in the presence of macroeconomic variables.

The results provide evidence of the relevance of aggregate labour market indicators. In fact, individual wages are shown to be:

1. negatively related to cohort size: in the age categories of wage earners where the ratio of the active to total population is higher, individual wages tend to be lower;

2. negatively affected by the unemployment rate prevailing in the Italian macro regions, with elasticities of magnitudes of between -0.046 and -0.063 for women, and between -0.053 and -0.096 for men, depending on the model specification, but in line with those found in similar studies on wage-curves;

3. positively influenced by the dynamics of union wages. The elasticity of individual earnings to union wages is close to $1(0.7$ and 0.8$)$, with the interesting result that the union wage index of equation (5) absorbs the variance explained by the constant term in the model of equation (2). It thus gives some economic meaning to the (so far unexplained) high constant term that characterises the simpler model of individual wages.

The results presented in this paper suggest that it would be possible and useful to integrate the changing age profiles of individual wages with the estimation and projections of Italian aggregate industry and service sector average wages. Two sets of countervailing factors would be at work here. On the one hand, productivity gains at the macro level would generate progressively increasing entry wages. On the other 
hand, the declining wage-age profiles would determine a lower growth in individual wages throughout the workers' life cycle than under time invariant wage expectations. This paper leaves open for future research investigation of the reasons why individual wage expectations in the Italian labour force are undergoing such significant changes. 


\section{Bibliography}

Baltagi, B.H. and Blien, U. (1998), "The German wage curve: evidence from the IAB employment sample", Economic Letters, Vol. 61.

Beaudry, P. and Green D. (2000), "Cohort patterns in Canadian earnings: assessing the role of skill premia in inequality trends", Canadian Journal of Economics, Vol. 33, No. 4.

Bell, B., Nickell, S. and Quintini, G. (2002), "Wage equations, wage curves and all that", Labour Economics, Vol. 9.

Berger, M.C. (1985), "The effect of cohort size on earnings growth: a re-examination of the evidence", The Journal of Political Economy, Vol. 93, No. 3.

Biagi, F. (2003), "Characterizing cohort patterns for Italian wages", paper presented at the workshop "Mercato del lavoro, istituzioni e distribuzione dei redditi", 29-30 May, Università degli Studi del Piemonte Orientale, Novara, Italy.

Blanchflower, D.G. and Oswald, A.J. (1994), The wage curve, MIT Press.

-- (1995), "An introduction to the wage curve", The Journal of Economic Perspectives, Vol. 9, No. 3.

-- (2005), "The wage curve reloaded", NBER, Working paper No. 11338.

Brugiavini, A. and Peracchi, F. (2003), "Social Security Wealth and Retirement Decisions in Italy", Labour, Vol. 17 (Special Issue).

Brunello, G. and Comi, S. (2000), "Education and earnings growth: evidence from 11 European countries", IZA Discussion paper, No. 140.

Brunello, G., Comi, S. and Lucifora, C. (2000), "The College wage gap in 10 European countries: evidence from two cohorts", IZA Discussion paper, No. 228.

Brunello, G. and Lauer, C. (2004), "Are wages in Southern Europe more flexible? The effects of cohort size on European earnings", IZA Discussion Paper, No. 1299.

Burbidge, J.B., Magee, L. and Robb, A.L. (1997), "Cohort, year and age effects in Canadian wage data", Canadian International Labour Network, Working paper No. 13.

Cappellari, L. (2000), "The covariance structure of Italian male wages", The Manchester School, Vol. 68, No. 6.

Card, D. (1995), "The wage curve: a review", Journal of Economic Literature, Vol. 33, No. 2. 
Card, D. and Lemieux, T. (2001), "Can falling supply explain the rising return to college for younger men? A cohort-based analysis", The Quarterly Journal of Economics, May.

Creedy, J. and Hart, P.E. (1979), "Age and the distribution of earnings", The Economic Journal, Vol. 89, No. 354.

Devicienti, F., Maida, A. and Pacelli, L. (2006), "The resurrection of the Italian wage curve", Laboratorio R. Revelli, Working paper No. 52.

Fabiani, S., Lovarno, A., Oneto, G. and Sestito, P. (1998), "Risultati e problemi di un quinquennio di politica dei redditi: una prima valutazione quantitativa", Bank of Italy, Working paper No. 329.

Fertig, M. and Schmidt, C.M. (2003), "Gerontocracy in motion? European crosscountry evidence on the labour market consequences of population ageing", IZA Discussion Paper, No. 956.

Gatto, R., Gennari, P. and Massarelli, N. (2001), "La ricostruzione e il riallineamento delle serie storiche delle forze di lavoro. Gennaio 1984-Luglio 1992", ISTAT, Rome.

Heckman, J.J. (1979), "Sample selection bias as a specification error", Econometrica, Vol. 47, No. 1.

Huber, P.J. (1967), "The behaviour of maximum likelihood estimates under nonstandard conditions", Proceedings of the Fifth Berkeley Symposium on Mathematical Statistics and Probability, Berkeley, CA: University of California Press, Vol. 1.

Korenman, S. and Neumark, D. (2000), "Cohort crowding and youth labour markets: a cross-sectional analysis", in Blanchflower, D. and Freeman, R. (eds.), Youth employment and joblessness in advanced countries, NBER, Chicago University Press.

Lucifora, C. and Rappelli, F. (1995), "Evoluzione delle retribuzioni nel ciclo di vita: un'analisi su dati longitudinali", Lavoro e relazioni industriali, No. 3.

Lucifora, C. and Vignocchi, C. (1997), "Le carriere retributive: un'analisi con microdati", in CNEL, Rapporto sulle retribuzioni e sul costo del lavoro, Giuffrè Editore.

Mincer, J. (1958), "Investments in human capital and personal income distribution", Journal of Political Economy, Vol. 56.

Moulton, B.R. (1986), "Random group effects and the precision of regression estimates", Journal of Econometrics, No. 32. 
Naticchioni, P., Ricci, A. and Rustichelli, E. (2006), "Return to education and changes in the wage structure: is there an unskilled bias technological change in Italy?", XXI National Conference of Labour Economics, University of Udine, Italy, 14-15 September.

Psacharopoulos, G. and Layard, R. (1979), "Human capital and earnings: British evidence and a critique", Review of Economic Studies, Vol. 46, No. 3.

Rogers, W.H. (1993), "Regression standard errors in clustered samples", Stata Technical Bulletin, Vol. 13. Reprinted in Stata Technical Bulletin Reprints, Vol. 3.

Stapleton, D.C. and Young, D.J. (1988), "Educational attainment and cohort size", Journal of Labour Economics, Vol. 6, No. 3.

Welch, F. (1979), "Effects on cohort size on earnings: the baby boom babies' financial bust", Journal of Political Economy, Vol. 87, No. 2.

White, H. (1980), "A heteroskedasticity-consistent covariance matrix estimator and a direct test for heteroskedasticity", Econometrica, Vol. 48. 


\section{APPENDIX A: FIGURES}

Figure 1. Sample, union and national accounts real wages (base 1999=100)

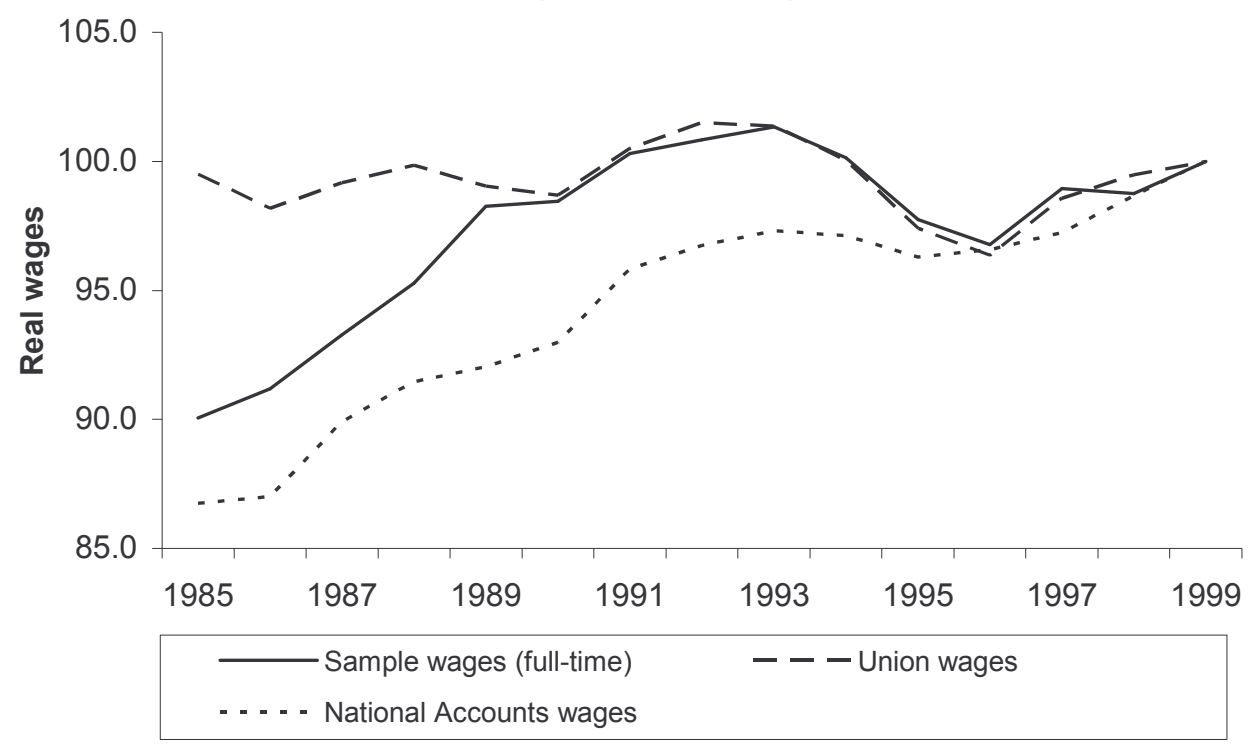

Figure 2. Base cohort model: men

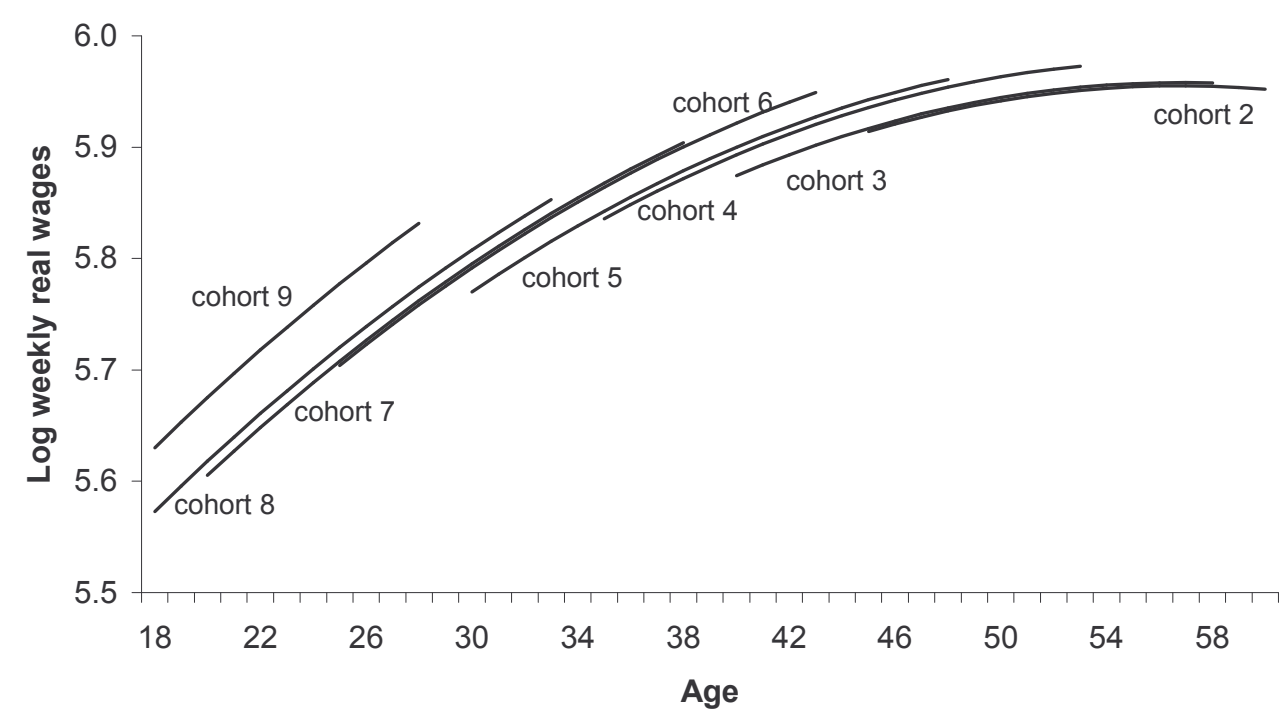


Figure 3. Multiplicative-cohort dummy model: men

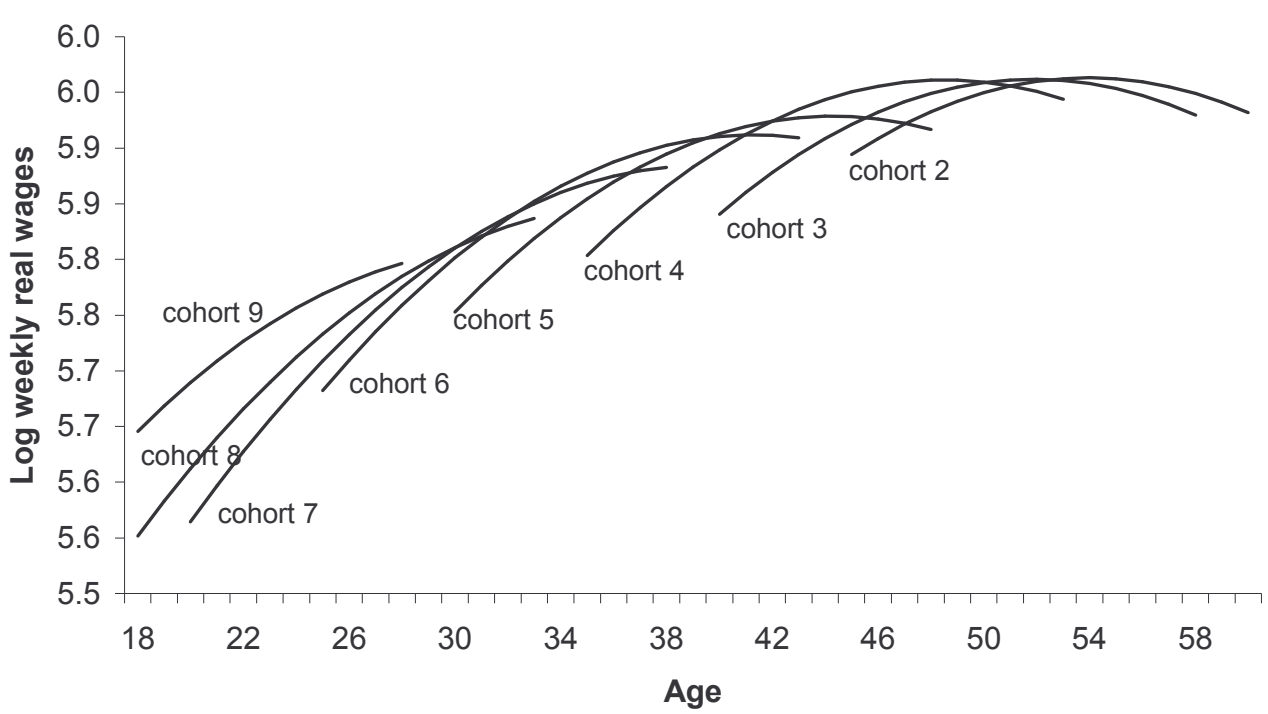

Figure. 4 Population cohort-size: men

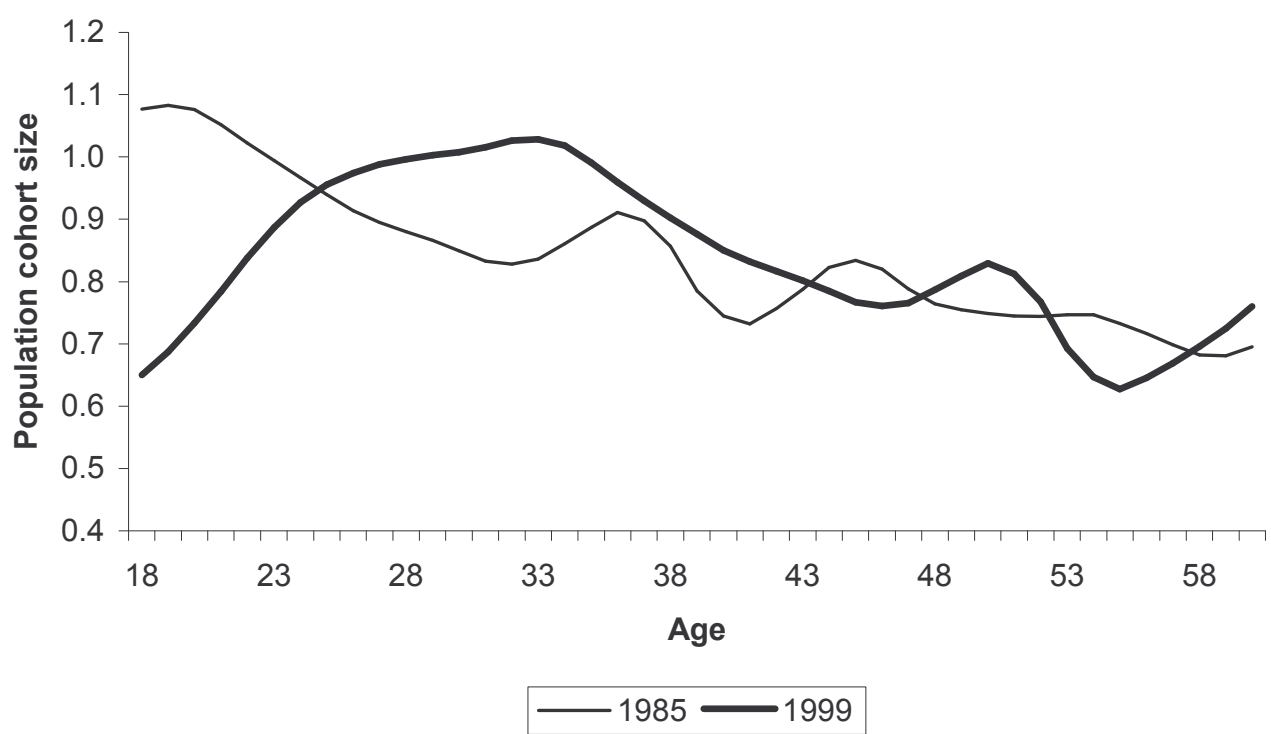


Figure 5. National and regional unemployment rates, 1985-1999

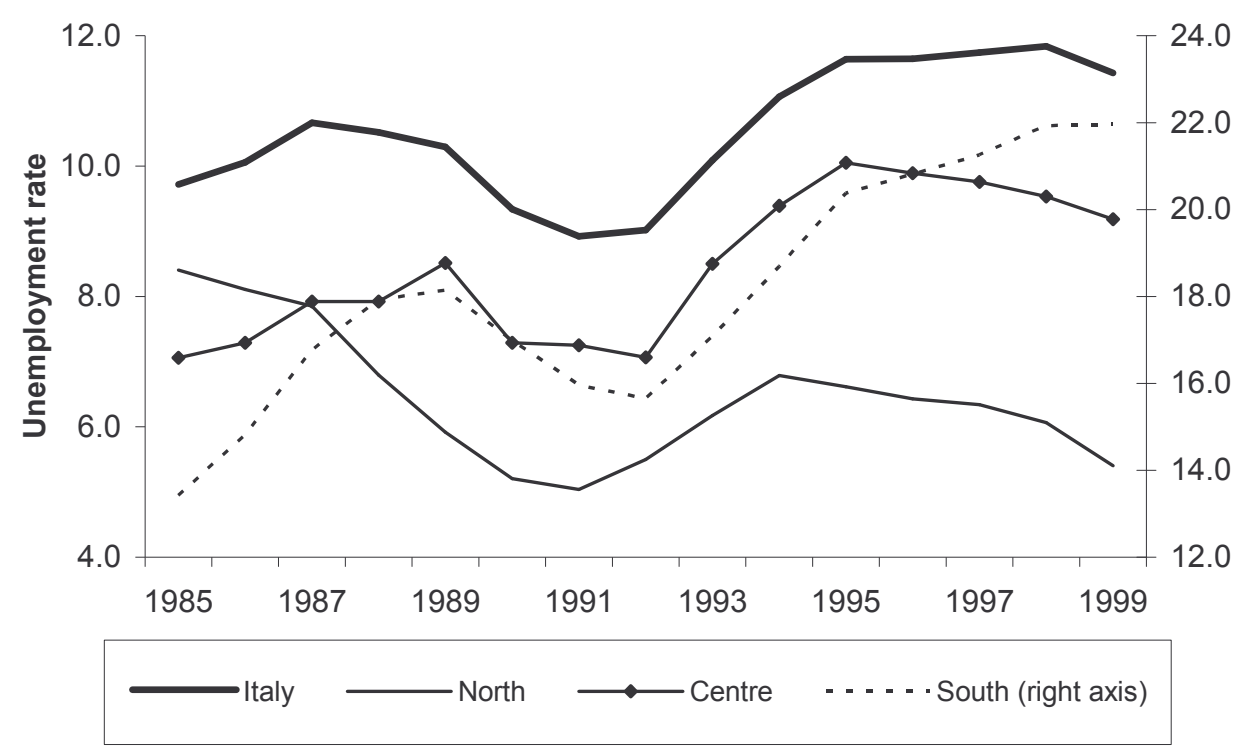




\section{APPENDIX B: TABLES}

Table 1 Sample composition by cohort

\begin{tabular}{lrrrrr}
\hline & Year of birth & Individuals & $\%$ & Observations & $\%$ \\
Cohort 1 & $1925-35$ & 6383 & 6.4 & 27612 & 4.0 \\
Cohort 2 & $1936-40$ & 5763 & 5.8 & 43732 & 6.3 \\
Cohort 3 & $1941-45$ & 6170 & 6.2 & 57430 & 8.3 \\
Cohort 4 & $1946-50$ & 8147 & 8.2 & 81950 & 11.9 \\
Cohort 5 & $1951-55$ & 8459 & 8.5 & 78208 & 11.3 \\
Cohort 6 & $1956-60$ & 11027 & 11.0 & 92026 & 13.3 \\
Cohort 7 & $1961-65$ & 15557 & 15.6 & 119056 & 17.3 \\
Cohort 8 & $1966-70$ & 17085 & 17.1 & 111283 & 16.1 \\
Cohort 9 & $1971-81$ & 21234 & 21.3 & 78593 & 11.4 \\
Total & & 99825 & 100 & 689890 & 100 \\
\hline
\end{tabular}

Table 2. Annual nominal and real wages of full-time workers

\begin{tabular}{|c|c|c|c|c|c|c|}
\hline \multicolumn{4}{|c|}{ Nominal wages } & \multicolumn{3}{|c|}{ Real wages } \\
\hline Year & Mean & Median & $\begin{array}{r}\text { Annual growth } \\
\text { rates of mean } \\
\text { wages }\end{array}$ & Mean & Median & $\begin{array}{r}\text { Annual growth } \\
\text { rates of mean } \\
\text { wages }\end{array}$ \\
\hline 1985 & 7962 & 8062 & & 15304 & 15494 & \\
\hline 1986 & 8537 & 8587 & 7.21 & 15494 & 15585 & 1.24 \\
\hline 1987 & 9210 & 9262 & 7.88 & 15850 & 15940 & 2.30 \\
\hline 1988 & 9909 & 9913 & 7.59 & 16192 & 16197 & 2.16 \\
\hline 1989 & 10879 & 10683 & 9.79 & 16699 & 16398 & 3.13 \\
\hline 1990 & 11684 & 11329 & 7.40 & 16732 & 16223 & 0.20 \\
\hline 1991 & 12825 & 12432 & 9.76 & 17045 & 16522 & 1.87 \\
\hline 1992 & 13493 & 12978 & 5.20 & 17136 & 16482 & 0.53 \\
\hline 1993 & 14139 & 13507 & 4.79 & 17222 & 16452 & 0.50 \\
\hline 1994 & 14570 & 14098 & 3.05 & 17018 & 16466 & -1.18 \\
\hline 1995 & 15140 & 14607 & 3.91 & 16609 & 16024 & -2.41 \\
\hline 1996 & 15662 & 15011 & 3.45 & 16445 & 15762 & -0.98 \\
\hline 1997 & 16260 & 15864 & 3.81 & 16812 & 16403 & 2.23 \\
\hline 1998 & 16517 & 16142 & 1.58 & 16781 & 16400 & -0.19 \\
\hline 1999 & 16993 & 16747 & 2.89 & 16993 & 16747 & 1.26 \\
\hline
\end{tabular}


Table 3. Weekly real wages of full-time workers

\begin{tabular}{|c|c|c|c|c|c|c|c|c|c|c|c|}
\hline & \multirow[b]{2}{*}{ Women } & \multirow[b]{2}{*}{ Men } & \multirow[b]{2}{*}{ Total } & \multicolumn{8}{|c|}{ Age class } \\
\hline & & & & $18-25$ & $26-30$ & $31-35$ & $36-40$ & $41-45$ & $46-50$ & $51-55$ & $56-60$ \\
\hline 1985 & 273 & 372 & 340 & 259 & 316 & 348 & 378 & 388 & 389 & 391 & 410 \\
\hline 1986 & 273 & 372 & 340 & 255 & 315 & 347 & 380 & 394 & 398 & 394 & 404 \\
\hline 1987 & 281 & 381 & 348 & 261 & 321 & 356 & 390 & 413 & 411 & 407 & 421 \\
\hline 1988 & 283 & 385 & 352 & 261 & 321 & 360 & 394 & 419 & 423 & 422 & 428 \\
\hline 1989 & 298 & 399 & 366 & 272 & 335 & 373 & 411 & 433 & 442 & 441 & 446 \\
\hline 1990 & 299 & 400 & 367 & 274 & 332 & 376 & 407 & 435 & 449 & 445 & 446 \\
\hline 1991 & 308 & 407 & 375 & 278 & 338 & 384 & 414 & 447 & 454 & 460 & 455 \\
\hline 1992 & 310 & 411 & 378 & 278 & 338 & 384 & 413 & 446 & 467 & 465 & 464 \\
\hline 1993 & 313 & 409 & 378 & 277 & 337 & 381 & 409 & 440 & 458 & 463 & 466 \\
\hline 1994 & 308 & 402 & 372 & 269 & 328 & 370 & 403 & 432 & 451 & 467 & 474 \\
\hline 1995 & 303 & 393 & 364 & 261 & 322 & 365 & 399 & 423 & 443 & 465 & 447 \\
\hline 1996 & 302 & 389 & 361 & 262 & 316 & 358 & 396 & 416 & 442 & 456 & 447 \\
\hline 1997 & 308 & 397 & 368 & 265 & 323 & 365 & 403 & 423 & 450 & 473 & 454 \\
\hline 1998 & 314 & 396 & 369 & 265 & 325 & 367 & 402 & 423 & 448 & 466 & 459 \\
\hline 1999 & 318 & 401 & 374 & 267 & 329 & 374 & 408 & 430 & 455 & 463 & 464 \\
\hline
\end{tabular}

Table 4. Weekly real wages by job qualifications and sector of activity of full-time workers

\begin{tabular}{lrrr}
\hline & Industry & Services & Total \\
Apprentice & 196 & 199 & 197 \\
Blue collar & 323 & 315 & 321 \\
White collar & 476 & 405 & 440 \\
White collar (senior) & 840 & 802 & 826 \\
Manager & 1220 & 1183 & 1210 \\
Total & 368 & 356 & \\
\hline
\end{tabular}

Table 5. Weekly real wages by firm dimension and area of work (full-time workers)

\begin{tabular}{lrrrrrr}
\hline \multicolumn{7}{c}{ Geographical area } \\
Firm dimension & North-West & North-East & Centre & South & Isles & All \\
$0-9$ & 308 & 295 & 278 & 248 & 248 & 285 \\
$10-19$ & 345 & 310 & 305 & 271 & 274 & 314 \\
$20-199$ & 397 & 361 & 345 & 312 & 299 & 364 \\
$200-999$ & 456 & 415 & 434 & 398 & 394 & 435 \\
$>=1000$ & 470 & 425 & 547 & 464 & 479 & 489 \\
All & 393 & 345 & 378 & 303 & 294 & \\
\hline
\end{tabular}


Table 6. Base cohort model

\begin{tabular}{|c|c|c|c|c|c|c|}
\hline & \multicolumn{3}{|c|}{ Women } & \multicolumn{3}{|c|}{ Men } \\
\hline & Number of obs & $=$ & 246419 & Number of obs & $=$ & 440910 \\
\hline & $F(21,128356)$ & $=$ & 4323.64 & $F(21,283514)$ & $=$ & 22127.2 \\
\hline & Prob $>$ F & $=$ & 0.0000 & Prob $>$ F & $=$ & 0.0000 \\
\hline & R-squared & $=$ & 0.2665 & R-squared & $=$ & 0.4621 \\
\hline & Coef. & & $\mathrm{t}$ & Coef. & & $\mathrm{t}$ \\
\hline age & 0.02123 & & 25.82 & 0.03392 & & 61.30 \\
\hline age2 & $-1.66 \mathrm{E}-04$ & & -14.22 & $-2.99 \mathrm{E}-04$ & & -40.47 \\
\hline dco2 & -0.01898 & & -2.37 & -0.01860 & & -5.42 \\
\hline dco3 & -0.00624 & & $-0.79\left(^{*}\right)$ & -0.01570 & & -4.09 \\
\hline dco4 & 0.00936 & & $1.12\left(^{*}\right)$ & 0.00302 & & $0.73\left(^{*}\right)$ \\
\hline dco5 & 0.03290 & & 3.64 & 0.00989 & & 2.13 \\
\hline dco 6 & 0.04903 & & 5.13 & 0.03146 & & 6.39 \\
\hline dco7 & 0.06830 & & 6.92 & 0.03508 & & 6.87 \\
\hline dco8 & 0.10378 & & 10.34 & 0.04760 & & 9.04 \\
\hline dco9 & 0.16128 & & 15.87 & 0.10469 & & 19.14 \\
\hline Icontr & 0.10597 & & 60.41 & 0.12300 & & 87.89 \\
\hline ptime & 0.08799 & & 34.94 & -0.00074 & & -0.14 \\
\hline d_centre & -0.05027 & & -24.51 & -0.01231 & & -9.72 \\
\hline d_south & -0.15092 & & -53.11 & -0.14373 & & -91.36 \\
\hline d_serv & -0.03528 & & -19.92 & -0.00842 & & -7.30 \\
\hline d_small & -0.04840 & & -27.16 & -0.10399 & & -82.53 \\
\hline d_large & 0.12383 & & 56.61 & 0.12850 & & 105.22 \\
\hline d_apprentices & -0.44946 & & -109.14 & -0.51178 & & -142.14 \\
\hline d_bluecollars & -0.29665 & & -174.24 & -0.30503 & & -249.95 \\
\hline d_managers & 0.96227 & & 29.08 & 0.82009 & & 250.63 \\
\hline const. & 5.04322 & & 320.58 & 5.01163 & & 468.13 \\
\hline
\end{tabular}

(*) Not significant at the 95\% confidence level. 
Table 7. Multiplicative-cohort model

$\begin{array}{rlr}\text { Women } \\ \text { Number of obs }= & 246419 \\ \mathrm{~F}(29,128348) & = & 3119.08 \\ \text { Prob }>\mathrm{F}= & 0.0000 \\ \text { R-squared } & = & 0.2675\end{array}$

Robust standard errors.

$\begin{array}{rrr}\text { Men } & \\ \text { Number of obs } & = & 440910 \\ \mathrm{~F}(29,283506) & = & 15930.61 \\ \text { Prob }>\mathrm{F}= & 0.0000 \\ \text { R-squared } & = & 0.4628\end{array}$

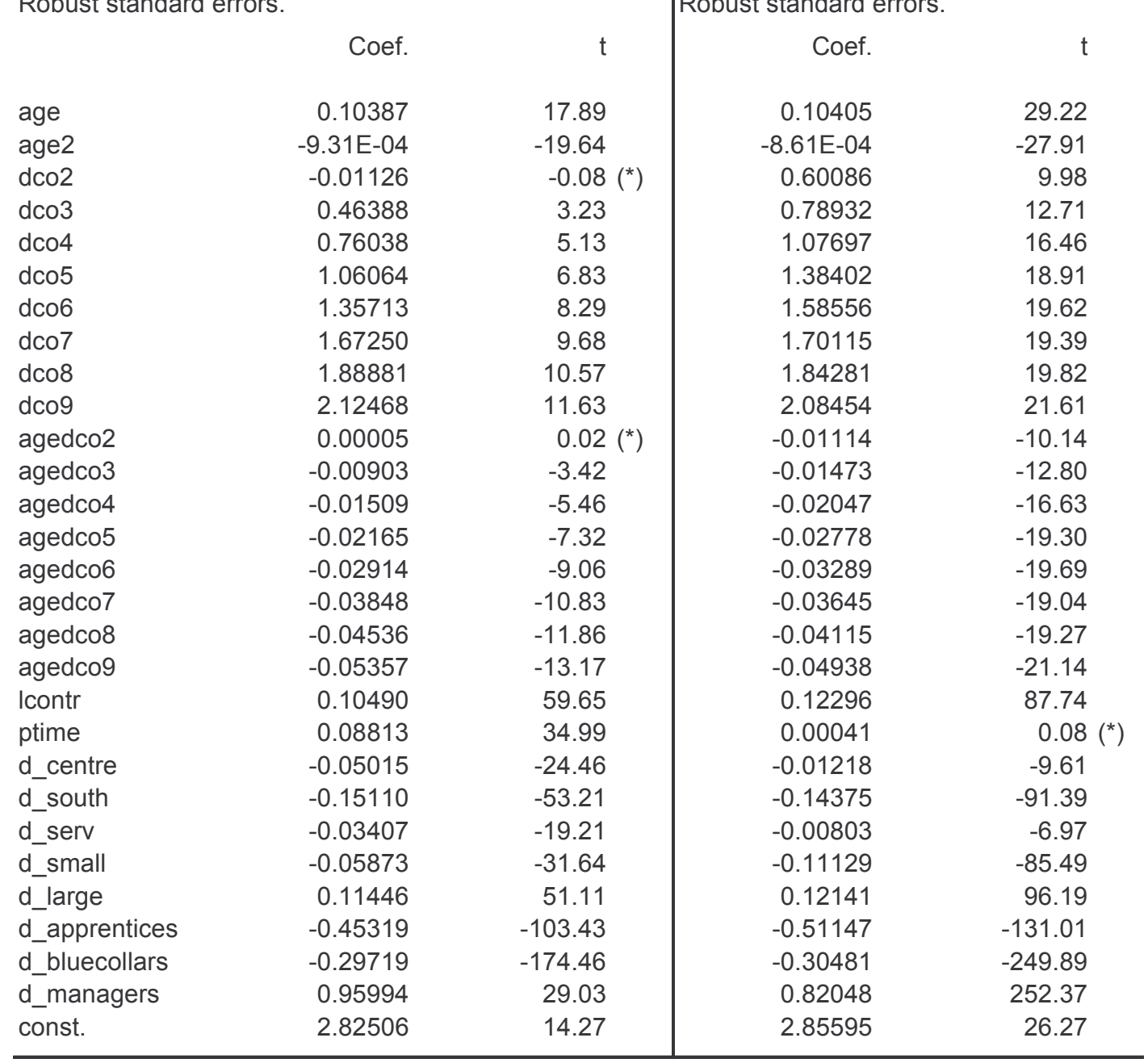

(*) Not significant at the 95\% confidence level. 
Table 8. Multiplicative-cohort model (random effects)

\begin{tabular}{|c|c|c|c|c|c|c|}
\hline & \multicolumn{3}{|c|}{ Women } & \multicolumn{3}{|c|}{ Men } \\
\hline & Number of obs & $=$ & 246419 & Number of obs & $=$ & 440910 \\
\hline & Number of groups & $=$ & 38686 & Number of groups & $=$ & 61077 \\
\hline & R-sq. within & $=$ & 0.0853 & R-sq. within & $=$ & 0.1461 \\
\hline & between & $=$ & 0.2542 & between & $=$ & 0.4212 \\
\hline & overall & $=$ & 0.2384 & overall & $=$ & 0.4208 \\
\hline & Coef. & & z & Coef. & & z \\
\hline age & 0.11718 & & 24.19 & 0.12636 & & 50.78 \\
\hline age2 & $-9.54 \mathrm{E}-04$ & & -24.35 & $-9.98 E-04$ & & -46.90 \\
\hline dco2 & 0.36987 & & 2.96 & 0.68491 & & 15.67 \\
\hline dco3 & 0.89808 & & 7.35 & 1.10678 & & 24.99 \\
\hline dco4 & 1.31962 & & 10.50 & 1.51602 & & 31.91 \\
\hline dco5 & 1.64791 & & 12.48 & 1.86846 & & 35.42 \\
\hline dco6 & 1.97818 & & 14.22 & 2.08851 & & 36.00 \\
\hline dco7 & 2.34474 & & 16.06 & 2.27365 & & 36.18 \\
\hline dco8 & 2.53183 & & 16.75 & 2.37430 & & 35.73 \\
\hline dco 9 & 2.63880 & & 17.04 & 2.50878 & & 36.19 \\
\hline agedco2 & -0.00704 & & -3.08 & -0.01214 & & -15.45 \\
\hline agedco3 & -0.01700 & & -7.62 & -0.02028 & & -25.28 \\
\hline agedco4 & -0.02549 & & -10.99 & -0.02829 & & -32.18 \\
\hline agedco5 & -0.03255 & & -13.05 & -0.03676 & & -36.05 \\
\hline agedco 6 & -0.04064 & & -14.96 & -0.04218 & & -35.73 \\
\hline agedco7 & -0.05133 & & -17.26 & -0.04754 & & -35.19 \\
\hline agedco8 & -0.05716 & & -17.86 & -0.05064 & & -33.70 \\
\hline agedco 9 & -0.05983 & & -17.43 & -0.05384 & & -32.15 \\
\hline Icontr & 0.11028 & & 48.51 & 0.12352 & & 71.21 \\
\hline ptime & 0.19283 & & 78.13 & 0.11996 & & 35.77 \\
\hline d_centre & -0.06123 & & -15.40 & -0.02971 & & -12.38 \\
\hline d_south & -0.15652 & & -33.92 & -0.13649 & & -54.07 \\
\hline d_serv & -0.04779 & & -18.44 & -0.02315 & & -14.51 \\
\hline d_small & -0.02093 & & -10.99 & -0.04413 & & -37.43 \\
\hline d_large & 0.03636 & & 14.34 & 0.04462 & & 36.49 \\
\hline d_apprentices & -0.35091 & & -73.62 & -0.35443 & & -104.57 \\
\hline d_bluecollars & -0.19292 & & -67.48 & -0.16355 & & -90.61 \\
\hline d_managers & 0.50092 & & 19.51 & 0.45833 & & 81.79 \\
\hline const. & 2.08177 & & 12.46 & 1.96407 & & 25.46 \\
\hline sigma_u & 0.32742 & & & 0.30676 & & \\
\hline sigma_e & 0.28728 & & & 0.21070 & & \\
\hline rho & 0.56502 & $\begin{array}{l}\text { frac } \\
\text { due }\end{array}$ & $\begin{array}{l}\text { of variance } \\
\text { i) }\end{array}$ & 0.67945 & ract & variance \\
\hline
\end{tabular}


Table 9. Model with regional unemployment rate and union wage

$\begin{array}{rr}\text { Women } \\ \text { Number of obs }= & 246419 \\ \text { R-squared }= & 0.2687\end{array}$

Number of clusters (year) $=15$

Robust standard errors.

\begin{tabular}{|c|c|c|c|c|}
\hline Robust standa & Coef. & $t$ & $\begin{array}{c}\text { Robust standard errors. } \\
\text { Coef. }\end{array}$ & $\mathrm{t}$ \\
\hline age & 0.07806 & 11.72 & 0.07275 & 10.74 \\
\hline age2 & -7.17E-04 & -13.10 & $-6.06 E-04$ & -9.78 \\
\hline dco2 & -0.13810 & $\left.-1.17 \quad \quad^{*}\right)$ & 0.45732 & 6.14 \\
\hline dco3 & 0.18233 & $\left.1.46 \quad{ }^{*}\right)$ & 0.45580 & 5.56 \\
\hline dco4 & 0.42419 & 2.84 & 0.66344 & 6.02 \\
\hline dco5 & 0.60843 & 3.96 & 0.83461 & 6.40 \\
\hline dco6 & 0.84273 & 4.68 & 0.96056 & 7.03 \\
\hline dco7 & 1.10982 & 5.64 & 1.01832 & 6.93 \\
\hline dco8 & 1.25828 & 6.24 & 1.08035 & 7.00 \\
\hline dco 9 & 1.42136 & 7.20 & 1.23823 & 7.11 \\
\hline agedco2 & 0.00232 & $\left.1.06 \quad{ }^{*}\right)$ & -0.00857 & -6.49 \\
\hline agedco3 & -0.00383 & $-1.67\left(^{*}\right)$ & -0.00855 & -5.81 \\
\hline agedco4 & -0.00843 & -2.99 & -0.01223 & -5.67 \\
\hline agedco5 & -0.01227 & -4.09 & -0.01639 & -6.15 \\
\hline agedco6 & -0.01784 & -4.72 & -0.01918 & -6.63 \\
\hline agedco 7 & -0.02507 & -5.77 & -0.02031 & -6.25 \\
\hline agedco8 & -0.02910 & -6.33 & -0.02173 & -6.04 \\
\hline agedco 9 & -0.03430 & -7.23 & -0.02648 & -5.75 \\
\hline Icontr & 0.10597 & 20.04 & 0.12344 & 15.04 \\
\hline ptime & 0.08824 & 8.17 & 0.00179 & $0.14\left(^{*}\right)$ \\
\hline d_centre & -0.04165 & -3.49 & 0.00860 & $1.49\left(^{*}\right)$ \\
\hline d_south & -0.12437 & -3.87 & -0.07679 & -3.30 \\
\hline d_serv & -0.03447 & -5.04 & -0.00841 & $-1.44\left(^{*}\right)$ \\
\hline d_small & -0.05696 & -9.60 & -0.11044 & -36.70 \\
\hline d_large & 0.11578 & 18.15 & 0.12116 & 38.10 \\
\hline d_apprentices & -0.45585 & -42.10 & -0.51479 & -47.51 \\
\hline d_bluecollars & -0.29702 & -61.11 & -0.30482 & -45.45 \\
\hline d_managers & 0.96319 & 31.39 & 0.81977 & 31.93 \\
\hline $\mathrm{cs}$ & -0.16306 & -3.79 & -0.16548 & -5.47 \\
\hline In_unemp & -0.02087 & $-0.99\left(^{*}\right)$ & -0.05345 & -3.64 \\
\hline In_wcontr & 0.92601 & 5.55 & 0.72396 & 7.79 \\
\hline const. & -0.49939 & $-0.63\left(^{*}\right)$ & 0.66205 & $1.27\left(^{*}\right)$ \\
\hline
\end{tabular}

(*) Not significant at the $95 \%$ confidence level. 
Table 10. Model with regional unemployment rate

$\begin{array}{rr}\text { Women } \\ \text { Number of obs }= & 246419 \\ \text { R-squared }= & 0.2679\end{array}$

$\begin{array}{rr}\text { Men } & \\ \text { Number of obs }= & 440910 \\ \text { R-squared }= & 0.4636\end{array}$

Number of clusters (year) $=15$

Robust standard errors.

Number of clusters (year) $=15$

Robust standard errors.

Coef.

$$
\text { Coef. }
$$

age

age2

0.08696

$\mathrm{t}$

dco2

dco 3

dco 4

dco5

dco 6

dco 7

dco8

dco 9

agedco2

agedco3

$-7.95 \mathrm{E}-04$

$-0.08106$

0.27851

0.55316

0.76699

1.02491

1.31211

1.47922

1.64902

0.00125

$-0.00572$

agedco4

$-0.01111$

$-0.01574$

agedco6

$-0.02205$

$-0.03006$

$-0.03492$

agedco8

$-0.04061$

0.10610

6.46

$-6.65$

$-0.68$

0.68
1.97

2.90

3.35

3.67

4.27

4.54

4.76

0.57

$-2.22$

$-2.99$

$-3.33$

$-3.55$

$-4.17$

$-4.40$

agedco 9

$-4.46$

Icontr

0.08828

19.33

ptime

$-0.03171$

8.24

$-2.29$

$-0.09262$

$-2.75$

d_south

$-0.03407$

$-4.92$

d_small

$-0.05825$

$-8.66$

d_large

0.11444

16.32

d_apprentices

$-0.45543$

$-41.43$

$-0.29708$

$-60.89$

d_managers

0.96245

31.47

cs

$-0.15126$

$-3.24$

$-0.04586$

$-2.13$

In_unemp

3.53431

8.42

$\begin{array}{rr}0.08010 & 6.29 \\ -6.69 \mathrm{E}-04 & -5.81 \\ 0.50522 & 6.72 \\ 0.53747 & 5.35 \\ 0.77149 & 4.67 \\ 0.96614 & 4.68 \\ 1.11269 & 4.78 \\ 1.18861 & 4.62 \\ 1.26474 & 4.49 \\ 1.42493 & 4.53 \\ -0.00945 & -7.05 \\ -0.01014 & -5.60 \\ -0.01445 & -4.34 \\ -0.01923 & -4.42 \\ -0.02265 & -4.40 \\ -0.02444 & -4.08 \\ -0.02649 & -3.82 \\ -0.03150 & -3.72 \\ 0.12349 & 15.03 \\ 0.00161 & 0.12\left(^{*}\right) \\ 0.01598 & 2.05 \\ -0.05305 & -1.86\left(^{*}\right) \\ -0.00830 & -1.42\left(^{*}\right) \\ -0.11104 & -33.08 \\ 0.12067 & 34.69 \\ -0.51403 & -47.58 \\ -0.30491 & -45.53 \\ 0.81956 & 31.85 \\ -0.15967 & -4.92 \\ -0.07231 & -3.95 \\ 3.80443 & 9.98 \\ & \\ & \end{array}$

(*) Not significant at the 95\% confidence level. 
Table 11. Model with regional unemployment rate and union wage (random effects)

$\begin{array}{rrr}\text { Women } & \\ \text { Number of obs }= & 246419 \\ \text { Number of groups }= & 38686 \\ \text { R-sq. within }= & 0.0881 \\ \text { between }= & 0.2556 \\ \text { overall }= & 0.2395\end{array}$

Std. error adjusted for 15 clusters in year

\begin{tabular}{|c|c|c|c|c|}
\hline & Coef. & $z$ & Coef. & $z$ \\
\hline age & 0.08199 & 10.21 & 0.08141 & 12.67 \\
\hline age2 & $-6.75 E-04$ & -11.52 & $-6.53 E-04$ & -12.27 \\
\hline dco2 & 0.13435 & $0.97\left(^{*}\right)$ & 0.39123 & 4.88 \\
\hline dco3 & 0.48663 & 2.84 & 0.57766 & 5.53 \\
\hline dco 4 & 0.79496 & 4.11 & 0.83527 & 7.14 \\
\hline dco5 & 0.99004 & 5.04 & 1.01436 & 7.64 \\
\hline dco6 & 1.22661 & 5.60 & 1.11950 & 7.69 \\
\hline dco7 & 1.52938 & 6.39 & 1.23073 & 8.25 \\
\hline dco8 & 1.64292 & 6.67 & 1.24068 & 7.69 \\
\hline dco 9 & 1.65189 & 6.40 & 1.25964 & 7.37 \\
\hline agedco2 & -0.00287 & $-1.13\left(^{*}\right)$ & -0.00696 & -5.13 \\
\hline agedco3 & -0.00964 & -3.09 & -0.01082 & -5.83 \\
\hline agedco4 & -0.01526 & -4.26 & -0.01497 & -7.20 \\
\hline agedco5 & -0.01927 & -5.18 & -0.01955 & -7.95 \\
\hline agedco6 & -0.02448 & -5.69 & -0.02140 & -7.66 \\
\hline agedco7 & -0.03218 & -6.58 & -0.02325 & -7.51 \\
\hline agedco8 & -0.03478 & -6.68 & -0.02246 & -6.43 \\
\hline agedco 9 & -0.03398 & -5.82 & -0.02168 & -5.22 \\
\hline Icontr & 0.11270 & 12.60 & 0.12562 & 10.36 \\
\hline ptime & 0.19288 & 9.51 & 0.12251 & 5.67 \\
\hline d_centre & -0.04508 & -2.57 & 0.00124 & $0.12\left(^{*}\right)$ \\
\hline d_south & -0.10681 & -2.84 & -0.03886 & $-1.41\left(^{*}\right)$ \\
\hline d_serv & -0.04839 & -6.02 & -0.02397 & -3.33 \\
\hline d_small & -0.01874 & -2.35 & -0.04296 & -3.91 \\
\hline d_large & 0.03823 & 3.39 & 0.04380 & 4.16 \\
\hline d_apprentices & -0.35380 & -33.59 & -0.35700 & -26.87 \\
\hline d_bluecollars & -0.19248 & -15.14 & -0.16257 & -10.69 \\
\hline d_managers & 0.50543 & 13.37 & 0.45443 & 53.02 \\
\hline $\mathrm{cs}$ & -0.27790 & -6.83 & -0.32391 & -7.27 \\
\hline In_unemp & -0.03811 & -2.14 & -0.07693 & -6.14 \\
\hline In_wcontr & 0.87856 & 6.71 & 0.70103 & 8.31 \\
\hline const. & -0.57864 & $-1.00\left(^{*}\right)$ & 0.50121 & 1.06 \\
\hline sigma_u & \multicolumn{2}{|l|}{0.32698} & \multicolumn{2}{|l|}{0.30652} \\
\hline sigma_e & \multicolumn{2}{|c|}{0.28683} & \multicolumn{2}{|c|}{0.20983} \\
\hline & \multicolumn{2}{|c|}{$\begin{array}{c}0.56513 \text { (fraction of variance } \\
\text { due to u_i) }\end{array}$} & \multicolumn{2}{|c|}{$\begin{array}{l}0.68091 \text { (fraction of variance } \\
\text { due to u_i) }\end{array}$} \\
\hline
\end{tabular}

(*) Not significant at the $95 \%$ confidence level. 
Table 12. Model with regional unemployment rate (random effects)

$\begin{array}{rrr}\text { Women } & \\ \text { Number of obs }= & 246419 \\ \text { Number of groups }= & 38686 \\ \text { R-sq. within }= & 0.0866 \\ \text { between }= & 0.2548 \\ \text { overall } & = & 0.2388\end{array}$

$\begin{array}{rlr}\text { Men } & & \\ \text { Number of obs } & = & 440910 \\ \text { Number of groups } & = & 61077 \\ \text { R-sq. within } & = & 0.1514 \\ \text { between } & = & 0.4202 \\ \text { overall } & = & 0.42\end{array}$

Std. error adjusted for 15 clusters in year

Std. error adjusted for 15 clusters in year

\begin{tabular}{|c|c|c|c|c|}
\hline & Coef. & $z$ & Coef. & $z$ \\
\hline age & 0.09161 & 6.85 & 0.08935 & 7.09 \\
\hline age2 & -7.57E-04 & -6.38 & $-7.18 E-04$ & -6.60 \\
\hline dco2 & 0.20546 & $1.58\left(^{*}\right)$ & 0.45682 & 5.27 \\
\hline dco3 & 0.59910 & 3.63 & 0.68040 & 5.31 \\
\hline dco4 & 0.94654 & 4.62 & 0.96773 & 5.55 \\
\hline dco5 & 1.17194 & 5.17 & 1.17084 & 5.50 \\
\hline dco6 & 1.43380 & 5.24 & 1.29747 & 5.23 \\
\hline dco7 & 1.75832 & 5.65 & 1.42737 & 5.24 \\
\hline dco8 & 1.88969 & 5.73 & 1.45089 & 4.86 \\
\hline dco9 & 1.91179 & 5.52 & 1.47714 & 4.57 \\
\hline agedco2 & -0.00420 & $-1.76\left(^{*}\right)$ & -0.00816 & -5.56 \\
\hline agedco3 & -0.01181 & -4.01 & -0.01277 & -5.77 \\
\hline agedco4 & -0.01836 & -4.82 & -0.01764 & -5.43 \\
\hline agedco5 & -0.02318 & -5.21 & -0.02284 & -5.45 \\
\hline agedco6 & -0.02919 & -4.99 & -0.02536 & -4.97 \\
\hline agedco7 & -0.03773 & -5.42 & -0.02792 & -4.66 \\
\hline agedco8 & -0.04114 & -5.48 & -0.02774 & -4.04 \\
\hline agedco9 & -0.04110 & -4.84 & -0.02742 & -3.35 \\
\hline Icontr & 0.11256 & 12.18 & 0.12541 & 10.06 \\
\hline ptime & 0.19299 & 9.57 & 0.12229 & 5.68 \\
\hline d_centre & -0.03520 & $-1.73\left(^{*}\right)$ & 0.00884 & $0.69\left(^{*}\right)$ \\
\hline d_south & -0.07553 & $-1.81\left(^{*}\right)$ & -0.01476 & $-0.43\left(^{*}\right)$ \\
\hline d_serv & -0.04766 & -5.86 & -0.02360 & -3.28 \\
\hline d_small & -0.02084 & -2.45 & -0.04404 & -4.21 \\
\hline d_large & 0.03594 & 2.94 & 0.04280 & 3.90 \\
\hline d_apprentices & -0.35330 & -33.71 & -0.35609 & -27.44 \\
\hline d_bluecollars & -0.19269 & -15.14 & -0.16280 & -10.74 \\
\hline d_managers & 0.50451 & 13.20 & 0.45365 & 51.24 \\
\hline$\overline{c s}$ & -0.26454 & -6.20 & -0.31283 & -7.55 \\
\hline In_unemp & -0.06269 & -3.09 & -0.09595 & -5.53 \\
\hline const. & 3.20738 & 7.68 & 3.50722 & 8.68 \\
\hline sigma_u & \multicolumn{2}{|l|}{0.32732} & \multicolumn{2}{|l|}{0.30680} \\
\hline sigma_e & \multicolumn{2}{|c|}{0.28707} & \multicolumn{2}{|c|}{0.21004} \\
\hline rho - & \multicolumn{2}{|c|}{$\begin{array}{c}0.56523 \text { (fraction of variance } \\
\text { due to } u_{i} i \text { ) }\end{array}$} & \multicolumn{2}{|c|}{$\begin{array}{c}0.68089 \text { (fraction of variance } \\
\text { due to } u \text { i) }\end{array}$} \\
\hline
\end{tabular}

(*) Not significant at the 95\% confidence level. 